\title{
Effect of retinoic acid on asbestos induced plasminogen activator activity of peritoneal macrophages
}

\author{
D LISON, B KNOOPS, R LAUWERYS
}

From the Unité de Toxicologie Industrielle, Faculté de Médecine, Université Catholique de Louvain, 1200 Brussels, Belgium

On the basis of epidemiological, morphological, and biochemical evidence, it has been proposed that asbestos acts as a tumour promotor.' Different phenomena are associated with tumour promotion, including production of reactive oxygen species and induction of various enzymatic activities such as ornithine decarboxylase and plasminogen activator (PA). ${ }^{2}$ Asbestos, like the classic tumour promoting agent, phorbol 12-myristate 13-acetate (PMA), stimulates the release of active oxygen species ${ }^{1}$ and stimulates plasminogen activation (PA) activity in macrophages both in vitro and in vivo. ${ }^{3}$

Retinoids are potent inhibitors of the tumourpromoting effects of PMA in different cellular systems (for a review see ref 4). Retinoic acid inhibits the production of reactive oxygen metabolites in human leukocytes stimulated by $\mathrm{PMA}^{5}$ and inhibits phorbol ester induced mouse epidermal ornithine decarboxylase. ${ }^{6-8}$ We have also observed (unpublished results) that retinoic acid prevents the in vitro PMA induction of membrane bound PA activity in macrophages. We have therefore investigated whether retinoic acid also modulates the induction of PA in mouse peritoneal macrophages stimulated by asbestos in vitro.

\section{Materials and methods}

\section{REAGENTS}

Balanced salt solution (BSS) was conditioned according to Earle's formula. Dulbecco's modified Eagle medium (DMEM), heat inactivated fetal calf serum (FCS), lactalbumin hydrolysate, and other culture products were purchased from GIBCO (Paisley, Scotland). Retinoic acid (all-trans) was from Sigma (St Louis, USA). The chromogenic substrate of plasmin S-2251 and human plasminogen were from Kabi Vitrum (Brussels, Belgium). Chrysotile fibres were a generous gift from Dr P Sébastien (CERCHAR,
Verneuil-en-Halatte, France). All other reagents were from Merck (Darmstadt, FRG).

\section{CULTURE PROCEDURE}

Culture conditions have been described in detaik elsewhere. ${ }^{9}$ Briefly, peritoneal macrophages were obtained from mice injected three days before with casein; they were plated in DMEM $+10 \%$ FCS in anpo atmosphere of $8 \%$ of $\mathrm{CO}_{2}$. Non-adherent cells were removed by thorough washing of the dishes. On theo second day of culture, the cells were stimulated with chrysotile fibres $(50 \mu \mathrm{g} / \mathrm{ml})$ for two hours. This stimulation phase was performed in a medium consist ing of DMEM supplemented with $0.1 \%$ lactalbumin hydrolysate.

\section{RETINOIC ACID TREATMENTS}

The influence of retinoic acid $\left(10^{-6} \mathrm{M}\right)$ was tested under three different conditions: (a) before chrysotile stimulation (this incubation was performed during 1 . minutes in BSS), (b) during the chrysotile stimulation $(2 \mathrm{~h}$ in DMEM $+0.1 \%$ lactalbumin), and (c) after stimulation (retinoic acid was added to the substrate medium).

\section{MEASURE OF PA ACTIVITY}

After removing the stimulation medium and thorougl washing, the cells were incubated for three to six hours in a medium containing S-2251 (0.3 mM) and human plasminogen $(0 \cdot 165 \mathrm{CU} / \mathrm{ml})$ in BSS.

Induced PA activity was assayed by measuring the amount of p-nitroaniline released in the medium (40) $\mathrm{nm})$. Each assay was run in triplicate with a plasmine ogen free blank.

\section{STATISTICAL ANALYSIS}

Statistical analysis was performed using analysis o variance and Scheffe's multiple comparisons test. 
Effect of retinoic acid $\left(10^{-6} \mathrm{M}\right)$ on the chrysotile stimulation of membrane bound plasminogen activator (PA) activity in mouse peritoneal macrophages in vitro

\begin{tabular}{ll}
\hline Incubation conditions & $\begin{array}{l}\text { PA activity }(\text { nmole } \\
\text { p-nitroaniline/10 cell/h) }\end{array}$ \\
\hline $\begin{array}{l}\text { Control } \\
\begin{array}{l}\text { Control preincubated for } 15 \text { minutes } \\
\text { with retinoic acid }\end{array}\end{array}$ & $4.40 \pm 0.24(\mathrm{~A})$ \\
$\begin{array}{l}\text { Chrysotile alone } 2 \mathrm{~h} \\
\text { Retinoic acid preincubated for } 15\end{array}$ & $3.04 \pm 0.06(\mathrm{~B})^{*}$ \\
$\begin{array}{l}\text { minutes before chrysotile } \\
\text { Retinoic acid added at same time as } \\
\text { chrysotile }\end{array}$ & $6.47 \pm 0.46(\mathrm{C})^{*}$ \\
$\begin{array}{l}\text { Retinoic acid added after incubation } \\
\text { with chrysotile }\end{array}$ & $2.33 \pm 0.18(\mathrm{D})$ \\
\hline
\end{tabular}

Mean \pm SD of three experiments.

*Means with the same letter do not significantly differ at the level of $5 \%$.

\section{Results and discussion}

In vitro treatment of mouse peritoneal macrophages by asbestos stimulates the expression of plasma membrane bound PA activity. In our system exposure of the macrophages to chrysotile for two hours stimulates the PA activity by a factor of $1 \cdot 5$. The influence of retinoic acid on this stimulation is summarised in the table. Preincubation of the macrophages during 15 minutes with retinoic acid $\left(10^{-6} \mathrm{M}\right)$ before exposure to chrysotile significantly depresses the induction of PA activity. This inhibition cannot be reversed by washing the cells before stimulation. Coincubation of the macrophages with retinoic acid and asbestos also prevents the induction of PA activity. Preincubation is slightly more efficient than coincubation with the inducer; binding of retinoic acid to the fibres may explain this observation. Retinoic acid alone incubated for 15 minutes with macrophages also slightly depresses the PA activity (about $70 \%$ of the control value). By contrast, addition of retinoic acid after the cells have been stimulated by chrysotile has no effect on the induced PA activity. Likewise, incubation of the purified enzyme during $\mathbf{3 0}$ minutes with retinoic acid $\left(10^{-5} \mathrm{M}\right)$ before addition of substrate does not affect its activity (data not shown). The inhibitory effect of retinoic acid on the induction of PA is independent of a global cytotoxic action; monitoring $\mathrm{LDH}$ release shows no cytotoxic effect of retinoic acid on macrophages up to $10^{-5} \mathrm{M}$ (data not shown).
These results indicate that a low concentration of retinoic acid inhibits the basal and the asbestos induced turnover of PA in macrophages but has no direct effect on the preformed enzyme; this inhibition occurs rapidly and is irreversible. Induction of PA activity in macrophages and other cell types is recognised as an important change accompanying tumour promotion and transformation of cultured cells. ${ }^{210}$

Inhibition of the induction of PA in macrophages may thus partly explain the antipromoting effect of retinoids.

The present results justify further studies on the chemopreventive role of retinoids, not only in asbestos induced neoplasias but also in asbestos induced lung fibrosis, since macrophages seem also to play a prominent part in the initiation of this lung reaction.

\section{References}

1 Mossman BT, Light W, Wei E. Asbestos: mechanisms of toxicity and carcinogenicity in the respiratory tract. Ann Rev Pharmacol Toxicol 1983;23:595-615.

2 Borman JS. Identification and assessment of tumor-promoting and co-carcinogenic agents: state-of-the-art in vitro methods. CRC Crit Rev Toxicol 1983;11:121-67.

3 Hamilton J, Vassalli JD, Reich E. Macrophage plasminogen activator: induction by asbestos is blocked by anti-inflammatory steroids. J Exp Med 1976;144:1689-94.

4 Lotan R. Effects of vitamin A and its analogs (retinoids) on normal and neoplastic cells. Biochim Biophys Acta 1980;605:33-91.

5 Kensler TW, Trush MA. Inhibition of phorbol ester stimulated chemiluminescence in human polymorphonuclear leukocytes by retinoic acid and 5,6-epoxy-retinoic acid. Cancer Res 1981; 41:216-22.

6 Verma AK, Shapes BG, Rice HM, Boutwell RK. Correlation of the inhibition by retinoids of tumor promotor-induced mouse epidermal ornithine decarboxylase activity and of skin tumor promotion. Cancer Res 1979;39:419-25.

7 Verma AK. Biochemical mechanism of inhibition of phorbol ester-induced mouse epidermal ornithine decarboxylase by retinoic acid. In: Meyskens FL, Prasad KN, eds. Vitamins and cancer. Human cancer prevention by vitamins and micronutrients. Clifton: Humana Press, 1985:35-49.

8 Verma AK. Inhibition of tumor promotor 12-0-tetradecanoylphorbol-13-acetate-induced synthesis of epidermal ornithine decarboxylase messenger RNA and diacylglycerol-promoted mouse skin tumor formation by retinoic acid. Cancer Res 1988; 48:2168-73.

9 Dubois $\mathbf{P}$, Lison D, Lauwerys $R$. Plasminogen activator activity of cultured murine macrophages and effects of isopropylmethylphosphonofiuoridate (sarin). Biochem Pharmac 1988;37: $2139-43$.

10 Danø K, Andreasen PA, Grondahl-Hansen J, Kristensen P, Nielsen LS, Skriver L. Plasminogen activators, tissue degradation, and cancer. Adv Cancer Res 1985;44:139-266. 